\title{
Imageological Co-relation of Pituitary Tumors with Per-op Findings
}

Authors

\section{Dr Pushkraj Baswant Birajdar ${ }^{1}$, Dr T.Narsimha Rao ${ }^{2}$}

${ }^{1}$ DNB Neurosurgery, Consultant Neurosurgeon Govt Medical College, Latur- 413512, Maharashtra, India

${ }^{2}$ Mch Neurosurgery, Senior Consultant Neurosurgeon, Care Hospital, Hyderabad-01

Email:nthiriveedi@yahoo.com

Corresponding Author

Dr Pushkraj Baswant Birajdar

C/o B.S.Birajdar, Sakar House, Near Jaikranti College, Sitaramnagar, Latur-413512, Maharashtra

Email: pushkrajb@gmail.com

\begin{abstract}
Our study is Prospective Study about correlation of MRI Brain Findings with Per-op Findings in case of Pituitary Tumors. This study was performed in 40 patients including both males \& females; new \& recurrent cases, in duration of $21 / 2$ years. All patients were undergone MRI Brain with special sequences for Pituitary Gland evaluation with other Hormonal analysis in some cases as per requirement .All patients were undergone Endoscopic Trans-sphenoidal Endonasal Excision of Pituitary Tumor. All patients were called for follow-up after 3 months for Surgical Excision evaluation with MRI Brain study. In follow-up cases we have studied our surgical achievement in relation of tumor clearance \& consider any need of adjuvant therapy like Radiation therapy.
\end{abstract}

Key Words: Pituitary, Endoscopic transphenoidal, MRI Brain, Hormonal, Adjuvant therapy.

\section{Introduction}

Pituitary gland tumors consist of $10-15 \%$ of all intracranial tumors.

They are responsible for Endocrinopathies and Pressure symptoms over optic apparatus, to cause significant morbidity \& mortality in general population.

Recent era, MRI Brain $(\mathrm{P}+\mathrm{C})$ with different sequences and views are available to study in detail about nature of Pituitary tumors.

These tumors having different Variable Consistency, so mostly are Unpredictable regarding Surgical Excision.

So this study deals with use of MRI Brain $(\mathrm{P}+\mathrm{C})$ to define criteria for involvement of vital structures by tumor \& tumor consistency in benefits of surgical outcome.

\section{Materials \& Methods}

- This is Prospective Study.

- It involves 40 patients over $2 \frac{1}{2}$ years duration $\&$ is performed at Care Hospital Group, Hyderabad.

Use of Specific Imaging:

$1.5 \mathrm{~T} 3 \mathrm{~mm}$ slice MRI Brain $(\mathrm{P}+\mathrm{C})$

-T 1/ T 2/ ADC/DWI,

-Coronal, Sagital, Axial views

- Surgery Planned: All patients were undergone Endoscopic Endonasal 
Transphenoidal Excision of Pituitary Tumor (Binostril approach)

\section{Inclusion Criteria}

- 5 years to 70 years age group

- Fresh and recurrent cases

- Males and females both

- Acute and chronic presentation both

\section{Exclusion Criteria}

- Very high risk patients with Anesthesia ASA grade 4/5

- Age $<5 y r$ and $>70$ year

- Recent major nasal surgery undergone cases

- Patients with bleeding disorders Hemophilia), coagulopathies

\section{Objective}

To co-relate mri brain $(\mathrm{p}+\mathrm{c})$ findings with per-op findings in terms of:

- Tumor Consistency,

- Invasive Nature of Tumor,

- Tumor Extension,

- Tumor Bleed

- Classify Tumor Accordingly.

To Plan Management of Pituitary Tumors in form:

- To decide The Extent of Surgical Excision of Tumor

- To get Histopathological Exact diagnosis \& classify tumor accordingly

- To achieve as much as possible maximum Tumor Clearance So that Hormonal Imbalance Symptoms or Pressure Symptoms caused by Tumor should be subsided at most.

- Post-op need of any Adjuvant Therapy in form of Radiation

\section{Others investigations}

- CT Paranasal sinuses

- Hormonal study- TFTs, Prolactin, Cortisol, $\mathrm{GH}$

- Visual field charting \& visual acuity
- Inferior Petrous venous sampling (microadenoma)

- Through general examination of patient

Our Hypothesis

If a Pituitary Tumor is

\begin{tabular}{|l|l|l|}
\hline Sr.No & MRI Brain Findings & $\begin{array}{l}\text { Per-op } \\
\text { Possibility }\end{array}$ \\
\hline 1 & $\begin{array}{l}\text { T 1: Isointense-Hypointense } \\
\text { T 2: Hyperintense }\end{array}$ & $\begin{array}{l}\text { Tumor should be } \\
\text { Soft }\end{array}$ \\
\hline 2 & $\begin{array}{l}\text { T 1: Isointense-Hypointense } \\
\text { T 2: Hypointnse }\end{array}$ & $\begin{array}{l}\text { Tumor should be } \\
\text { Firm to Hard }\end{array}$ \\
\hline 3 & $\begin{array}{l}\text { T 1: Isointense-Hypointense } \\
\text { T 2: Hyperintense } \\
\text { FLAIR: Hyperintense }\end{array}$ & $\begin{array}{l}\text { Tumor should be } \\
\text { Cystic }\end{array}$ \\
\hline 4 & $\begin{array}{l}\text { T 1 :Isointense-Hypointense } \\
\text { T2: Mixed } \\
\text { (Hypointense \&Hyperintense) }\end{array}$ & $\begin{array}{l}\text { Tumor should be } \\
\text { Mixed. } \\
\text { More Part of T 2 } \\
\text { is Hypointense } \\
\rightarrow \text { More is tumor } \\
\text { firmness. }\end{array}$ \\
\hline
\end{tabular}

\section{Clinical Presentation for Surgery}

Most of pituitary tumors patients may be found to be asymptomatic for long time till it causes notifying abnormality.

Clinical presentation is due to -

1. Hormonal Imbalance

2. Mass Effect of tumor

Mass effect produced of tumors may cause-

- Headache

- Visual disturbances

- Intracranial Hemorrhage

- Raised Intracranial Pressure Changes

- The most common symptoms caused by mass effect by tumor is Visual Impairment:

- Bitemporal Hemianopia(62\%)

- Unilateral Temporal Hemianopia(26\%)

- Optic Atrophy \& Loss of Vision (39\%).

口 Involvement of Cavernous Sinus by Pituitary Tumor may manifest as extraocular nerve palsies (3rd, 4th, 6th cranial nerves involvement)

\section{Hormonal Imbalance \& Manifestation:}

- Hyperprolactinomas present as-

Females-Infertilty,

Amenorrhoea,

Galactrhoea 
Males-Loss of Libido, Impotance.

- Somatotropinomas- Gigantism and Acromegaly presentation

- Corticotropinomas-usually are microadenomas, presents as Cushing's disease manifestation.

- Thyrotropinomas- presents as secondary hyperthyroidism changes

- Gonadotropinomas- most of time they are asymptomatic, usually are microadenomas. They rarely cause testicular enlargement in males and ovarian hyperstimulation changes in females.

\section{Analysis of Study}

1. Types of Pituitary Tumors in our study:

\begin{tabular}{|c|c|c|}
\hline Sr.No & Type of Pituitary Tumor & $\begin{array}{c}\text { Number of } \\
\text { Cases }\end{array}$ \\
\hline 1 & $\begin{array}{c}\text { Non-Functional Pituitary } \\
\text { Macroadenoma }\end{array}$ & 18 \\
\hline 2 & $\begin{array}{l}\text { Cushing's Disease } \\
\text { (Microadenomas) }\end{array}$ & 3 \\
\hline 3 & Rathke's Cleft Cyst & 3 \\
\hline 4 & $\begin{array}{c}\text { Somatotropinomas } \\
\text { (Acromegaly) }\end{array}$ & 5 \\
\hline 5 & Giant Pituitary Tumor & 2 \\
\hline 6 & $\begin{array}{c}\text { Invasive Pituitary } \\
\text { Carcinoma }\end{array}$ & 1 \\
\hline 7 & $\begin{array}{l}\text { Recurrent Pituitary } \\
\text { Macroadenoma }\end{array}$ & 5 \\
\hline 8 & Pure Pituitary Apoplexy & 1 \\
\hline 9 & $\begin{array}{c}\text { Functional Pituitary } \\
\text { Prolactinoma }\end{array}$ & 1 \\
\hline 10 & Lymphocytic Hypophysitis & 1 \\
\hline
\end{tabular}

Surgical Excision of Pituitary Tumors achieved in our study:

\begin{tabular}{|l|c|c|}
\hline Sr.No. & $\begin{array}{c}\text { Surgical Excision } \\
\text { Extent }\end{array}$ & $\begin{array}{c}\text { Number of } \\
\text { Cases }\end{array}$ \\
\hline 1 & Total & 9 \\
\hline 2 & Near Total & 12 \\
\hline 3 & Subtotal & 9 \\
\hline 4 & Partial & 6 \\
\hline 5 & Biopsy & 3 \\
\hline 6 & Marsupialization & 1 \\
\hline
\end{tabular}

Pituitary Tumor Consistency

\begin{tabular}{|l|c|c|c|}
\hline Sr.No & $\begin{array}{c}\text { Consistency of } \\
\text { Tumor }\end{array}$ & $\begin{array}{c}\text { MRI Brain } \\
\text { Findings } \\
\text { (No.ofCases) }\end{array}$ & $\begin{array}{c}\text { Per-op } \\
\text { Findings } \\
\text { (No.of Cases) }\end{array}$ \\
\hline 1 & Soft & 15 & 13 \\
\hline 2 & $\begin{array}{c}\text { Mixed } \\
\text { (Firm+ Soft) }\end{array}$ & 16 & 17 \\
\hline 3 & Firm to Hard & 9 & 10 \\
\hline
\end{tabular}

Statistical Analysis

\begin{tabular}{|l|c|c|c|c|c|c|}
\hline $\begin{array}{l}\text { Sr. } \\
\text { No. }\end{array}$ & $\begin{array}{c}\text { Before } \\
\text { MRI }\end{array}$ & Mean & $\begin{array}{c}\text { Std. } \\
\text { Dev. }\end{array}$ & After Per-op & Mean & $\begin{array}{c}\text { Std.Dev } \\
.\end{array}$ \\
\hline 1 & $\begin{array}{c}\text { MRI : } \\
\text { Consist- } \\
\text { ency }\end{array}$ & 1.400 & $\begin{array}{c}0.42 \\
4\end{array}$ & $\begin{array}{c}\text { Per-op Tumor } \\
\text { Tissue } \\
\text { Consist-ency }\end{array}$ & 1.485 & 0.485 \\
\hline
\end{tabular}

\begin{tabular}{|l|l|l|l|l|}
\hline $\begin{array}{l}\text { Sr.No } \\
.\end{array}$ & $\begin{array}{l}\text { Paramete- } \\
\text { rs }\end{array}$ & $\begin{array}{l}\text { Correlati- } \\
\text { on } \mathrm{r}\end{array}$ & $\begin{array}{l}\text { Cohen's } \\
\text { Kappa }\end{array}$ & Interpretat- ion \\
\hline 1 & $\begin{array}{l}\text { MRI: } \\
\text { Consist- } \\
\text { ency }\end{array}$ & 0.871 & 0.836 & $\begin{array}{l}\text { Almost nearly } \\
\text { perfect } \\
\text { Agreement }\end{array}$ \\
\hline
\end{tabular}

\section{Conclusion}

1) We have found as per our hypothesis about co-relation of mri brain intensity signals with per-op findings is satisfactorily proved.

2) So around in 33 cases (83-84\%) in our study hypothesis has been proved.

3) Only in 7 cases our hypothesis was not proven because of variation in per-op findings in case of tumor consistency.

4) Thus, by knowing pre-operatively we can predict about tumor consistency, its invasive nature \& plan for extent of surgical excision.

5) Also on basis of surgical extent of excision we can plan about need of post-op adjuvant therapy.

6) So pre-op mri brain $(p+c)$ with special sequences study is essential for the pituitary tumor management in relation with surgical clearance of disease.

\section{Index Cases}

1.Hypothesis proved(Soft Tumor)

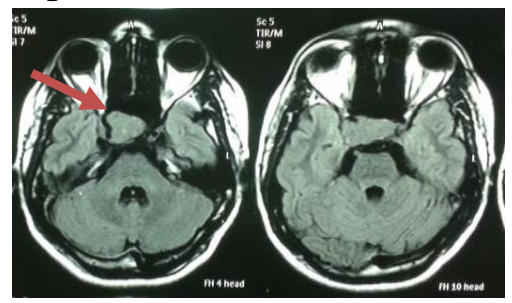

Fig.1: T1 image

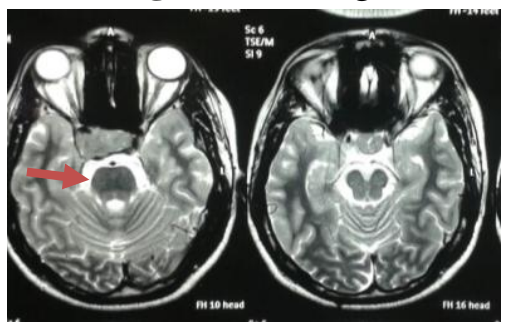

Fig.2: T2 image 


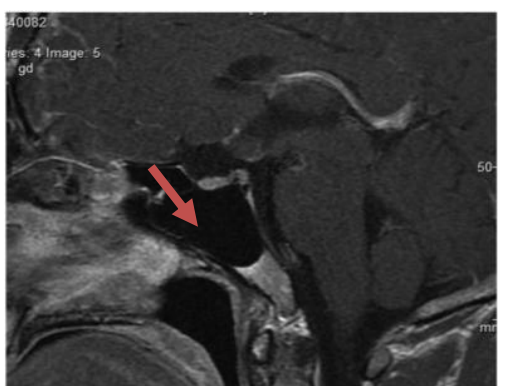

Fig 3: Total excision

2.Hypotheis not proved (Hard Tumor):

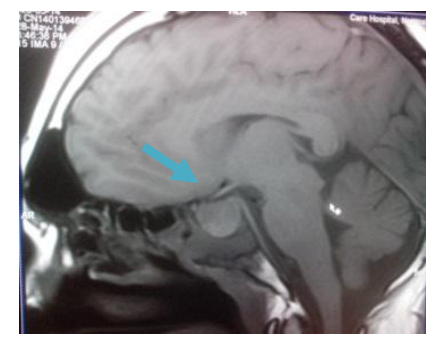

Fig.4: T1 image

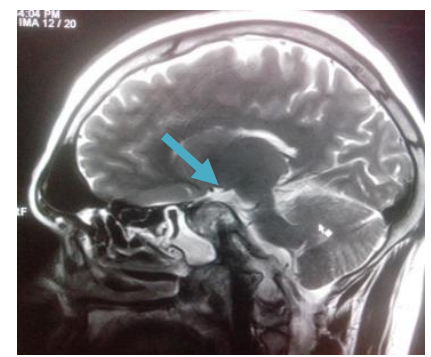

Fig.5: T2 image

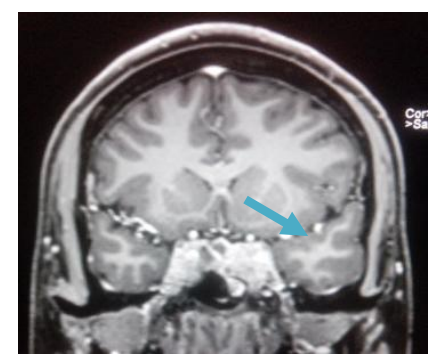

Fig.6: Partial Excision

\section{Acknowledgement}

I would like to express the deepest appreciation to my guide. Dr.T.Narsimha Rao, Senior Consultant Neurosurgeon; the Department of Neuro Surgery, CARE Institute of Medical Sciences, Hyderabad who has the attitude and the substance of a genius. He has continuously and convincingly conveyed a spirit of knowledge to the research and teaching. Without his guidance and persistent help, this thesis would not have been possible.
I would like to place my thanks on record for everybody, including the staff of CARE Hospitals, who were important for the successful realization of this thesis. I owe my thanks to my family for providing constant support and encouragement. Last but not the least I thank all my patients who in their periods of sorrow and sufferings have made my study possible with their kind cooperation.

Collective and individual acknowledgements are also owed to my colleagues in the Department of Neuro Surgery and other Departments, whose presence is perpetually refreshing, helpful and memorable.

\section{References}

1. Arafah BM, Harrington JF, Madhoun ZT \& Selman WR. Clinico-radiological Presentation of Pituitary tumors. Journal of Clinical Endocrinology and Metabolism 199071 323-328.

2. Bonneville JF, Bonneville F, Cattin F 2005 Magnetic resonanceImaging of pituitary ade nomas.Eur Radiol 15:543-548.

3. Cavallo LM, Messina A, Cappabianca P, Esposito F, de Divitiis E, and Tschabitscher M: Endoscopic endonasal surgery of the midline skull base: anatomical study and clinical considerations.Neurosurg Focus 19:e2, 2005.

4. Daly AF, Rixhon M, Adam C, Tichomirowa MA. High prevalence of pituitary adenomas: cross-sectional study.

J Clin Endocrinol Metab 91:47694775 [PubMed: 16968795].

5. Kaufman B, Kaufman BA, Arafah BM, Roessmann U, Selman WR. Large pituitary gland adenomas evaluated with MRI. Neurosurgery 1987; 21: 540-546.

6. Rennert J, Doerfler A. 2007. Imaging of sell ar and parasellar lesions.Clin Neurol Neuros urg 109:111- 124 [PubMed: 17126479].

7. Sakamoto Y, Takahashi M, Korogi Y, Bussakhi H, Ushio Y. Normal and abnormal pituitary glands: gadopentate dimeglumine 
enhanced MR imaging. Radiology 2007; 178:441- 445.

8. Schmidt RF, Choudhry OJ, Takkellapati R, Eloy JA, Couldwell WT and Liu JK: Hermann Schloffer and the origin of transsphenoidal pituitary surgery. Neurosurg Focus 33: e5, 2012.

9. Selman WR, Laws E, Scheithauer E, Carpenter S. The occurrence of dural invasion in pituitary adenomas.J Neurosurgery 1986; 64:402-407.

10. Buchfelder M. Management of aggressive pituitary adenomas: Current treatment strategies: Pituitary 2009:12(3);256-60.

11. Chong BW, Kucharczyk W, George S. Pituitary gland MR: a comparative study of healthy volunteers and patients with microadenomas.Am J Neuroradiol. 1994;15:675-679.

12. Daita G, Yonemasu Y, Nakai H, Takei H, Ogawa K. Cavernous sinus invasion by pituitary adenomas: relationship between MRI findings and histologically verified dural invasion. Neurol Med Chir Tokyo 1995; 35:17-21. 